\title{
Between Power and Process: Legal and Political Control over (Inter)national Security ${ }^{\dagger}$
}

\author{
Hayley J. Hooper ${ }^{*}$
}

\begin{abstract}
Securing fair procedures in the realm of (inter)national security has historically been much more difficult than in other realms of administration. It is necessary to steer a course between the national and the international, and law and politics. Any conception of the relationship between these forums and values will have different consequences, for both institutions tasked with the protection of security, and for persons affected by sanctions. This review of Devika Hovell's The Power of Process: The Value of Due Process in Security Council Sanctions Decision-Making argues that the presence of binding legal rulings against the exercise of such power remains an essential complement to innovative political forms of control such as an international Ombudsperson.
\end{abstract}

Keywords: national security, procedural fairness, international law, administrative law.

\section{Introduction}

Close your eyes, picture your morning routine. You wake up, amble downstairs and make coffee. You collect the mail: the usual reassuring mess of flyers, bills, and assorted junk. But there is also a letter postmarked from a government department. It explains that you have been designated a terrorist suspect by a committee of the United Nations Security Council (UNSC), and all of your financial assets have been frozen. No further explanation is offered.

The relationship between the individual, the state, and the international order in the context of counter-terrorism and security cuts across legal disciplines. Individuals in the situation described above are directly affected by this complex network of intersecting legal systems and power sharing relationships. It is to Devika Hovell's credit that she seeks to make sense of these complexities by traversing the fault lines between domestic public law and public international law in her thought-provoking book The Power of Process. ${ }^{1}$ Hovell provides a bold argument for conceiving of procedural fairness (synonymous with due process) beyond the strictures of law and courts. She analyses due process in the specific context of the UNSC sanctions regime against Al Qaeda, the Taliban, and ISIL, created by Resolution 1267 (1997). ${ }^{2}$

\footnotetext{
† A review of Devika Hovell, The Power of Process: The Value of Due Process in Security Council Sanctions Decision-Making (OUP 2016).

* Hayley J. Hooper, Christ Church, University of Oxford. Email: hayley.hooper@law.ox.ac.uk. With thanks to Alison L. Young, Liz Fisher, and the Anonymous Reviewer for helpful comments and guidance. All errors, omissions, and inaccuracies are mine alone.

${ }^{1}$ Devika Hovell, The Power of Process: The Value of Due Process in Security Council Sanctions Decision-Making (OUP 2016) 135.

${ }^{2}$ UNSC Res 1267 (15 October 1999) UN Doc S/RES/1267.
} 
It is a work of evident scholarly depth which provides fresh insights regarding the relationship between courts, administration, and the international order.

The Power of Process seeks to move notions of due process beyond a traditional court centric approach. Hovell's argument seeks to vindicate the much maligned office of the Ombudsperson, which was established to monitor the operation of the sanctions regime after a number of high profile adverse legal rulings concerning the regime's fairness. Hovell's argument views the balance between the competing imperatives of security and fairness from a 'top down' international perspective. This review essay considers procedural fairness from the opposite direction, i.e. from the perspective of a suspect subject to sanctions, seeking to vindicate their rights from the 'bottom up' (i.e. through a curial process in a municipal legal system). It argues that the legal conception of procedural fairness is a more pressing requirement than Hovell's analysis suggests. This is especially true in view of the marginalised political position terrorist suspects occupy within the international order and the constitutional order of nation states. Hovell's perspective is not wholly misconceived by any means, but there are a number of underlying assumptions which render parts of the analysis somewhat vulnerable, at least from the perspective of a domestic public lawyer. The core critique advanced in this essay is that whilst the analysis presents an innovative perspective on process values from the perspective of public international law, Hovell's argument undervalues the essential nature of access to binding legal remedies in municipal courts.

\section{Structure and Argument}

\subsection{Hovell’s Taxonomy of Procedural Fairness}

Hovell outlines a theoretical conception of procedural fairness which, if applied to the sanctions regime, will enhance its overall legitimacy. Legitimacy involves situating authority within the values of a given community, so as to promote the acceptance of that authority. ${ }^{3}$ Process values instantiate a dialogue between decision makers and the 'community to whom the decisions relate. ${ }^{4}$ To this end, Hovell presents the reader with a rich conception of the theoretical and practical dimensions of due process. She argues process values are a 'touchstone for the way in which a particular legal order conceives of far larger issues'. ${ }^{5}$ She neither contests the utility of the sanctions regime, nor acts as an apologist. The aim of 'smart sanctions', which target individuals and organisations, as opposed to nation states, is to ensure that restrictions bite in the appropriate location. They are to be contrasted with state sanctions which target governments in violation of international law. Often the latter sanctions are ineffective, due to the fact that governments can shift the economic burden onto 'innocent and often oppressed civilian populations.' 6

Hovell aims to develop a conception of procedural fairness that is both appropriate for the international institutional context and 'normatively rich'. ${ }^{7}$ The analysis presents three

\footnotetext{
${ }^{3}$ Hovell (n 1) 62.

${ }^{4}$ Hovell (n 1) 58.

5 ibid 58.

${ }^{6}$ Hovell (n 1) 11.

${ }^{7}$ Hovell (n 1) 4.
} 
models of procedural fairness developed 'through centuries of Anglo-American constitutional history and civilisation'. 8 These are the 'instrumentalist model', the 'dignitarian model', and finally, the 'public interest' model. Hovell favours the latter model.

The instrumental model of procedural fairness focuses on accuracy. It aims to ensure that decision makers accurately apply substantive legal rules to disputes. Accuracy competes with other values, such as 'financial cost, delay, and complication'. ${ }^{9}$ Instrumentalism is generally vindicated by court-centric processes, and is viewed by Hovell as lacking any substantive normative content ${ }^{10}$ because broader functions such as 'accountability, the balancing of interests, and representation of community values... are assumed already to be reflected in the substantive law. ${ }^{, 11}$

By contrast, the dignitarian model seeks to vindicate the dignity of the individual affected by a decision. This usually takes the form of a right to a hearing to contest the decision. Franz Kafka's The Trial ${ }^{12}$ is singled out as the vignette which provides the strongest justification for dignitarianism. ${ }^{13}$ The protagonist Josef $\mathrm{K}$ is at the mercy of an anonymous, secretive bureaucracy, unable to confront his accusers. He is eventually executed. Dignitarianism is underpinned by the values of dignity, self-respect, and autonomy. However, Hovell argues these values are 'ultimately amorphous and indeterminate.' ${ }^{14}$ She argues this model should not be founded upon liberal theory which prioritises the individual as the central legal and political actor. Instead dignitarianism should draw upon a 'pluralist conception of legal and political culture' ${ }^{15}$ reflecting all relevant perspectives, and involving 'a process of free negotiation or uninhibited bargaining among the various participants. ${ }^{16}$ The dignitarian model, therefore, does not necessarily require a curial process because it promotes a more 'open architecture' in relation to conceptions of community, law, and the relevant underlying values. ${ }^{17}$ However, for Hovell, these laudable aims are difficult to achieve as the dignitarian model contains no clear conception of the common good. ${ }^{18}$ This results in a potentially unequal distribution of power, decision-making becomes a bargaining process among competing elites. ${ }^{19}$ The result is that the model does not cater adequately to a 'rule of law framework' ${ }^{20}$

Finally, the public interest model exists to promote the value of public accountability. Procedural fairness under this model ensures that the 'law and policy in question has been fairly adopted by procedures which enable all citizens to exert an influence, however limited, in any particular case. ${ }^{21}$ This model is the least court-centric of the three, because it seeks to encourage wide participation and a 'wider sharing of legal authority' ${ }^{22}$ Due to its ambitions to decentralise power, this model is heavily reliant on the 'existence of a shared body of values

\footnotetext{
${ }^{8}$ Joint Anti-Fascist Refugee Committee v McGrath 341 US 123 (1951), per Justice Frankfurter.

${ }^{9}$ Hovell (n 1) 64.

${ }^{10}$ Hovell (n 1) 64

${ }^{11}$ Hovell (n 1) 67.

12 Franz Kafka, The Trial (first published 1937, Idris Parry tr, Penguin Modern Classics 2015).

${ }^{13}$ Hovell (n 1) 69.

14 ibid 69.

${ }^{15}$ Hovell (n 1) 73.

16 ibid 73.

${ }^{17}$ Hovell (n 1) 74.

${ }^{18}$ Hovell (n 1) 76.

${ }^{19}$ Hovell (n 1) 74.

${ }^{20}$ Hovel (n 1) 76.

${ }^{21}$ Hovell (n 1) 78, emphasis original.

${ }^{22}$ Hovell (n 1) 78-79.
} 
existing alongside (or more accurately, hierarchically superior to) substantive law. ${ }^{23}$ The public interest model does not see the rule of law as having fixed content: it will be influenced by a process of communication between participants which will be 'enabled by procedural safeguards'. ${ }^{24}$ This broad constituency participating in decision-making contributes to an ongoing justification of the use of power. ${ }^{25}$

However, the three categories are not necessarily as hermetically sealed as presented. For example, dignitarian justifications for procedural fairness are capable of serving both the individual and public interest and promoting public accountability. Several high profile cases from the UK Supreme Court concerning access to justice and the adequacy of reason giving demonstrate the ability of individuated decisions to serve communitarian purposes, and public accountability. In UNISON the majority considered the notion that bringing a claim was a 'purely private activity' to be 'demonstrably untenable' ${ }^{26}$ because '[a]ccess to the courts is not... of value only to the particular individuals involved. ${ }^{27}$ Furthermore, In Dover DC $v$ CPRE Kent the Supreme Court held that adequate reason giving by a planning authority served both the individual and the public interest. ${ }^{28}$ Similarly, judgments concerning national security measures are of importance because of either their articulation or interpretation of principles of general importance. ${ }^{29}$ The dignitarian vision of due process may remain necessary to complement the international functioning of the public interest theory of due process, which Hovell claims is underpinned by the 'emerging "cosmopolitan constitutionalist" school of thought. ${ }^{30}$ Whilst there is no agreed definition of 'cosmopolitan constitutionalism' it broadly promotes the classical liberal values of private autonomy and economic freedom over 'political freedom and...collective self-government. ${ }^{31}$ If cosmopolitan constitutionalism enhances the prospects of the already economically emancipated global citizen, it may not immediately prioritise the procedural rights of the terrorist suspects, whose treatment under the sanctions regime renders them de facto 'prisoners of the state'. ${ }^{32}$ In this regard, it is not immediately clear that the 'public interest model' is capable of making a discrete contribution to understandings of procedural fairness.

\subsection{The Ombudsperson as the Institutional Realisation of the Public Interest Model}

Hovell sees the office of the Office of the Ombudsperson of the Security Council's 1267 Committee (hereinafter 'the Ombudsperson') ${ }^{33}$ as a more appropriate locus for procedural protection than either national or supra-national courts. Support for the office is based up three factors, namely, the appropriateness the Ombudsperson in the specific context, a general

\footnotetext{
${ }^{23}$ Hovell (n 1) 79.

${ }^{24}$ Hovell (n 1) 80.

${ }^{25}$ Hovell (n 1) 79.

${ }^{26}$ R (UNISON) v Lord Chancellor [2017] WLR(D) 552; [2017] UKSC 51 [67].

${ }^{27}$ UNISON (n 26) [69].

${ }^{28}$ Dover District Council v CPRE Kent [2017] WLR(D) 812; [2017] UKSC 79 [55].

${ }^{29}$ Home Secretary v AF (No. 3) [2009] UKHL 28; [2010] 2 AC 269.

${ }^{30}$ Hovell (n 1) 143-144.

${ }^{31}$ Martin Loughlin, 'The end of avoidance' (2016) 38(15) London Review of Books 12.

${ }^{32}$ HM Treasury v Ahmed (No. 1) [2010] 2 WLR 378 [60].

33 The Office of the Ombudsperson to the ISIL (Da'esh) and Al-Qaida Sanctions Committee $<$ www.un.org/sc/suborg/en/ombudsperson>.
} 
critique of adjudication, and finally a specific critique of the applicability of human rights law standards to the Security Council. The Ombudsperson is considered to be better placed than the 'internationalised or pluralist judicial frameworks' ${ }^{34}$ to vindicate the public interest conception of procedural fairness because it has the 'capacity to promote a subtle shift in classical conceptions of community, law, and values'. ${ }^{35}$ This is partly because the Ombudsperson works on an inquisitorial as opposed to adversarial conception of process. An inquisitorial process helps the Ombudsperson to engage the Security Council community in a discourse that ultimately contributes to the development of a 'more representative set of decisions and applicable norms. ${ }^{36}$ The Ombudsperson's role involves 'information-gathering, consultation, and outreach' with a wide range of constituents, including the petitioner. ${ }^{37}$ The process involves a de novo review of listing cases according to 'consistent and contextually appropriate standards' ${ }^{38}$ Finally, the Ombudspersons approach to review is dynamic: '[u]nlike judicial review [it] is not frozen in time' and can respond to changing circumstances. ${ }^{39}$

The Ombudsperson's decisions are non-binding and require voluntary compliance from the Security Council. In practical terms, Hovell considers the Ombudsperson to be more effective than the diffuse network of judicial decisions relating to smart sanctions because it is a cheap, relatively quick process which does not require legal representation (although it does provide a hearing for the affected party insofar as possible). The Ombudsperson is considered more effective than the court process because it definitively secures the delisting of suspects. At the time of writing the Ombudsperson had obtained the delisting of thirty-four individuals and twenty-seven entities. ${ }^{40}$ The most high profile delisting concerns Yassin Abdullah Kadi, the Egyptian national who, despite having several landmark judgments in his favour from the European Union judicature ${ }^{41}$, did not directly secure delisting via litigation.

Hovell considers the 1267 regime particularly unsuitable for legal regulation for two further over-arching reasons. First, fairness is ultimately contextual, and secondly, that the adjudicatory model cannot be squared with the standards of procedural fairness which are realistically achievable in the Security Council context. The court-based framework is defined as 'a logically coherent and complete system of principles and rules, where decisions are reached through the presentation of proofs in trial type hearings and are amenable to authoritative review by an independent arbiter. ${ }^{42}$ However, Hovell acknowledges that there is no universally applicable model of procedural fairness, as these vary both from legal system to legal system, and within legal systems. Underlying these differences are, of course 'different ideas as to the process values that [a] procedural framework can and should support. ${ }^{43}$ The main drawbacks with the application of a legal due process is that judicial standards (in the broadest sense) are typically designed to control the distribution of powers in a domestic, as opposed to international, legal system. Moreover, the vindication of such a system requires a

\footnotetext{
${ }^{34}$ Hovell (n 1) 141.

${ }^{35}$ Hovell (n 1) 144.

${ }^{36}$ Hovell (n 1) 143.

${ }^{37}$ Hovell (n 1) 146.

${ }^{38}$ Hovell (n 1) 149.

${ }^{39}$ ibid.

${ }^{40}$ Hovell (n 1) 28.

${ }^{41}$ Kadi and Al Barakaat International Foundation v Council and Commission (Kadi No. 1) [2008] ECR I-6351; Commission v Kadi (Kadi No. 2) [2013] ECR 00000 (Grand Chamber).

${ }^{42}$ Hovell (n 1) 38.

43 ibid.
} 
'minimal commitment to certain institutional tenets' such as an independent judiciary, and the need to 'defend a charge publicly and with reference to known law.' 44 The UN Security Council does not have an independent judiciary, nor a system of legal rules relating to individual conduct which mirrors that of any of the permanent member states.

Hovell astutely notes that conceptual distinctions within domestic and international human rights law do not accurately map onto the UN sanctions regime Attempts to regulate the 1267 regime using human rights law standards risks further contributing to the 'distorted conception of procedural fairness' already present in the international sphere. ${ }^{45}$ This distortion is partly stems from the dichotomy between 'civil' and 'criminal' procedures in human rights law. Criminal proceedings generally engender higher standards of procedural protection than their civil counterparts. Smart sanctions are usually classified as civil or administrative measures, and as such attract lower standards of protection. ${ }^{46}$ Furthermore, the civil/criminal divide is not easily applicable to the Security Council as an institution, because it views listing as an 'administrative political act, beyond judicial review'. ${ }^{47}$ Moreover, curial notions of procedural fairness are inapposite because the Sanctions Committee cannot readily be categorised as either a judicial or an executive body. It is a hybrid of both. In short, the civil/criminal divide is 'not a feature of security council decision-making. ${ }^{48}$

Hovell's third concern is that human rights law is not capable of shifting its standards of procedural fairness in the event of an emergency requiring derogation from generally accepted norms. ${ }^{49}$ Although most human rights treaties recognise the right of states to derogate from certain rights in times of public emergency, derogation does not define the core standards of procedural fairness which cannot be abandoned. ${ }^{50}$ For Hovell, this compels the conclusion that the Ombudsperson is the most appropriate actor to oversee the imposition of smart sanctions because it can effectively pressure states politically to reveal the information behind the decision to list individuals or entities. ${ }^{51}$ In tandem with this, the frequent public reports issued by the Ombudsperson makes the international community aware of instances of noncooperation and compliance failure by member states. ${ }^{52}$

\section{The 'Smart' Sanctions Regime: Context, Rationale, and Development}

Hovell's claim that binding courts decisions are problematic and impact negatively upon the operation and legitimacy of the sanctions regime requires analysis in its broader context. The 1267 regime was deliberately designed to elude the legal accountability provided by legal standards enforced by courts. The regime itself is firmly in the hands of executive actors as

\footnotetext{
${ }^{44}$ Hovell (n 1) 39.

${ }^{45}$ Hovell (n 1) 31-32.

${ }^{46}$ Bank Mellat v HM Treasury (No. 1) [2013] UKSC 38; [2013] WLR(D) 244; Al Rawi v Security Services [2012]

1 AC 531; [2011] UKSC 34 [187].

${ }^{47}$ Hovell (n 1) 47.

${ }^{48}$ Hovell (n 1) 48.

${ }^{49}$ Hovell (n 1) 32.

${ }^{50}$ Hovell (n 1) 50.

${ }^{51}$ Hovell (n 1) 156.

${ }^{52}$ Hovell (n 1) 157.
} 
opposed to democratically accountable institutions. Smart sanctions are a new international regime to freeze assets 'on the basis of evidence that might not stand up in court ... Because the funds would be frozen, not seized, the threshold of evidence [can]be lower and the net wider.' 53 Hovell's claim that 'courts are part of the problem' ${ }^{54}$ comes under strain when we step back and consider the broader context in which the UNSCR 1267 regime operates.

The UNSCR 1267 sanctions regime is aimed at the activities of Al Qaeda, the Taliban, and (the now deceased) Osama Bin Laden. The regime was later extended to include ISIS/Da'esh. ${ }^{55}$ It requires states to do two things: (1) to recommend persons in their territory suspected of financial or other links to Al Qaeda, the Taliban or ISIS to be added to a centrally administered UNSC list (the ' 1267 Consolidated List'), and (2) to immediately freeze the funds of those persons already on the list within their territory. UNSCR 1267 (1999) established a committee known as the ' 1267 Committee' responsible for the administration of the 'Consolidated List'. Initially, the presence of due process was weak or non-existent. Given the nature of the subject matter (often information from national intelligence agencies), 'there is no burden of proof as such for imposing sanctions'. ${ }^{56}$ Although the regime has existed since the late 90s listing criteria and disclosure requirements have been developed incrementally. ${ }^{57}$ The process is highly secretive: designating states have the right to maintain their confidentiality, even to the suspect. Those listed are required to be informed ${ }^{58}$ but disclosure $^{2}$ of reasons only amounts to 'narrative summaries published on the Committee's website'. ${ }^{59}$

Smart sanctions were designed to disrupt the efforts of international terrorism. ${ }^{60}$ In short 'terrorists rarely kill for money, but they always need money to kill' ${ }^{61}$ Clearly, it was designed to be 'court proof' as the above statement indicates. The broader response to international terrorism post $9 / 11$ (of which the 1267 regime became a central component) is part of 'a new global security law [which] now coordinates the diverse efforts of states around the world in a common campaign against terrorism.' ${ }^{62}$ Underpinning this new 'global security law' is a blurring of 'the boundary between domestic policing and international intelligence'. ${ }^{63}$ Notably these intelligence sharing relationships often take the form of 'concentric rings' as part of carefully managed relationships between the executive branches of member states. ${ }^{64}$

The move away from traditional legal evidentiary standards towards reliance upon secret intelligence is acknowledged by Hovell as the most common subject matter dealt with

\footnotetext{
${ }^{53}$ Quoted in Marieke De Goede, 'The Politics of Preemption and the War on Terror in Europe' (2008) 14 European Journal of International Relations 161, 163-164, 166, emphasis added.

${ }^{54}$ Hovell, (n 1) 135.

55 UNSC Res 2253 (17 December 2015) UN Doc S/RES/2253.

56 Simon Chesterman, 'The Spy Who Came in from the Cold War: Intelligence and International Law' (20052006) 27 Michigan Journal of International Law 1071, 1110.

${ }^{57}$ Adele J Kirshener, 'Security Council Resolution 1904 (2009): A Significant Step in the Evolution of the AlQaida and Taliban Sanctions Regime?’ (2010) 70(3) Heidelberg Journal of International Law 585, 589-591.

${ }^{58}$ UNSCR 1735 (2006).

${ }^{59}$ UNSCR 1822 (2008) in Kirshener (n 57) 591.

${ }^{60}$ On Al Qaeda’s financial structure see Victor Comras, 'Al Qaeda Finances and Funding to Affiliated Groups' in Jeanna K. Giraldo and Harold A. Trinkunas (eds), Terrorism Financing and State Responses: A Comparative Perspective (Stanford University Press 2007) 115-133.

${ }^{61}$ Directorate General Internal Policies of the Union, Policy Department C, Citizens Rights and Constitutional Affairs, Overview of European and International Legislation on Terrorist Financing, April 2009, PE 410. 695, 8.

${ }^{62}$ Kim Lane Scheppele, 'Global Security Law and the Challenge to Constitutionalism After 9/11' [2011] PL 353377, 355-356.

63 De Goede (n 53) 162.

${ }^{64}$ Chesterman (n 56) 1093.
} 
by the Ombudsperson ${ }^{65}$, and as a frequent justification for the denial of reason giving in domestic legal rulings concerning national security. ${ }^{66}$ However, beyond this, the difficulties caused by secret intelligence for the concept of due process are not further fleshed out by Hovell. Although there is no agreed definition of intelligence, the term is generally taken to mean classified information which is held by the Government for the purposes of protecting national security or conducting foreign relations. ${ }^{67}$ Intelligence of this nature will be classified by governments, as its dissemination is considered harmful to the public interest. Therefore, intelligence is a shorthand for 'secret intelligence'.

Secret intelligence, in contrast to evidence admissible in civil or criminal proceedings, is often predictive and contingent in nature. Sir David Omand, the former Intelligence and Security Coordinator at the Cabinet Office, explains that intelligence reports: 'include statements about the depth and adequacy of the intelligence base...usually with a predictive flavour ("It is likely that..." etc.). ${ }^{68}$ It creates problems for the traditional notions of causeand-effect upon which so much of common law principle is based: "In the old days, the only ascertainable cause-and-effect relations tended to be one of the " $A$ hit $B$ "...variety: one cause that was of interest to the law and one readily identifiable effect, following closely upon the cause.' ${ }^{69}$ There is growing concern that the reliance upon predictive intelligence riskassessments to impose sanctions undermines the relationship with causation inherent in much of the law, in favour of the weaker principle of correlation. ${ }^{70}$

Reliance upon intelligence and intelligence agencies has driven sanctions further from legal standards of fairness towards norms built upon the ethos of intelligence agencies. In 1999 the understanding of Islamist international terrorism was dramatically different from the present, post-9/11, perspective. Omand explains that: 'Security cannot be achieved within a single country...We have a patchwork of formal and informal arrangements with institutions that find it hard to shed long-held habits of protecting turf or restricting inter-institutional cooperation. ${ }^{71}$ The use of intelligence to facilitate such regimes post-9/11 was '[c]haracterized by secrecy, flexibility, and informality, the intelligence sharing networks are constrained almost exclusively by a shared professional ethos, rather than law. ${ }^{, 72}$

Hovell considers the UNSCR 1267 regime in isolation. However, the smart sanctions regime, forms part of an emerging category of executive-driven initiatives which reflect a transition away from traditional norms of criminal procedure. Smart sanctions belong in a context along with other pre-emptive administrative national security measures designed to prevent terrorism instituted at nation state level. This category includes control orders ${ }^{73}$ (and their successor regime terrorism prevention and investigation measures) ${ }^{74}$, parallel regimes of terrorist asset freezing, and immigration control measures such as deportation and deprivation

\footnotetext{
${ }^{65}$ Hovell (n 1) 155.

${ }^{66}$ Hovell (n 1) 18.

67 Michael Warner, 'Wanted: A definition of “intelligence”' (2002) Central Intelligence Agency (Defence Technical Information Centre 2002), and Written Security Briefing for Members of European Parliament: $<$ www.guengl.eu/uploads/publications-documents/ERNST2.doc $>$

${ }^{68}$ David Omand, Securing the State (C Hurst \& Co Publishers Ltd 2012) 38-39, emphasis added.

${ }^{69}$ Richard A Posner, Catastrophe: Risk and Response (OUP 2004) 9.

${ }^{70}$ Victor Mayer-Schönberger and Kenneth Cukier, Big Data: A Revolution That Will Transform How We Live, Work and Think (John Murray Publishers 2013) 157-163.

${ }^{71}$ David Omand, 'Countering International Terrorism: The Use of Strategy' (2005) 47 (4) Survival: Global Politics and Strategy 107, 110-111.

${ }^{72}$ Elizabeth Sepper, 'Democracy, Human Rights, and Intelligence Sharing' (2010-2011) 46 Texas International Law Journal 153, 153, emphasis added.

${ }^{73}$ Prevention of Terrorism Act 2005.

${ }^{74}$ Terrorism Prevention and Investigation Measures Act 2011.
} 
of citizenship. Collectively, these measures form part of a system of 'preventive justice'. ${ }^{75}$ This new species of sanctions has largely been driven by the wants and needs of security bureaucracies because 'seeking security from terrorism has the quality of a trump card. ${ }^{, 76}$

The shift from legal procedures to softer forms of political control like the Ombudsperson must also be understood against together with the fact that legislation and legal norms are largely epiphenomenal to the existence of security and intelligence agencies even in Western Liberal Democracies. Spying or intelligence gathering has been described cynically as 'the second oldest profession'. By contrast 'intelligence accountability is a recent phenomenon'. ${ }^{77}$ The Security Service, or 'MI5' existed for some eighty years before the introduction of the Security Service Act 1989, section one of which states: 'There shall continue to be a Security Service'. ${ }^{78}$ By way of a more recent example, the Prevention of Terrorism Act 2005, which established the regime of control orders for those 'reasonable suspected' of involvement in terrorism, was heavily influenced by the needs of the Security Service (MI5): 'crucial phases of law-making were not fully public...The actual involvement of security and police agencies, while profound, was shrouded in secrecy. Indeed, the British Security Service...is said to have drafted the Prevention of Terrorism Bill; a fact only revealed after the Bill had passed into law. ${ }^{79}$ This represents a departure from common practice, as legislation is usually drafted by Parliamentary Counsel, not executive agents. ${ }^{80}$ The interests of national security remain primarily an executive issue at nation state level. Courts have struggled hard to reinject legal control into this 'parallel' regime. ${ }^{81}$ When individual rights (which are often 'human' or 'constitutional' in nature) are at stake, and no recourse to a suitably democratic forum is available, Hovell's claim that courts are 'part of the problem' comes under strain.

\section{The Double Democratic Deficit in Global Security Law}

Hovell begins from the position that the Security Council was never designed to be democratic in nature. ${ }^{82}$ This is undoubtedly true. The Security Council and cooperating intelligence agencies are not analogous to a representative legislature. They are bureaucratic, as opposed to democratic, and work behind a veil of secrecy. She rightly does not dismiss concerns about the democratic deficit outright, instead suggesting that her 'public interest model' of procedural fairness strikes at the heart of the 'democratic deficit' present in the UN Security Council. ${ }^{83}$

\footnotetext{
${ }^{75}$ Lucia Zedner, 'Preventive Justice or Pre-Punishment: The Case of Control Orders' (2007) 60 CLP 174, 174.

${ }^{76}$ Lucia Zedner, 'Terrorism and counterterrorism: What is at risk?' in Layla Skinns, Michael Scott \& Tony Cox (eds), Risk (CUP 2011) 109. See also Andrew Ashworth and Lucia Zedner, Preventive Justice (OUP 2014) Ch 9. ${ }^{77}$ Lawrence Lustgarten and Ian Leigh, In From the Cold (OUP: Clarendon Press 1994) 1.

${ }^{78}$ Security Service Act 1989, s 1, emphasis added.

${ }^{79}$ Joo-Cheong Tham, 'Parliamentary Deliberation and the National Security Executive: The Case of Control Orders’ [2010] PL 79, 84.

${ }^{80}$ Daniel Greenberg, Laying Down the Law: A Discussion of the People, Processes and Problems that Shape Acts of Parliament (Sweet \& Maxwell 2011) Section 3.

${ }^{81}$ Eminent Jurists’ Panel, 'Assessing Damage, Urging Action: Report of the Eminent Jurists Panel on Terrorism, Counter-terrorism and Human Rights’ (International Commission of Jurists 2009) 120.

${ }^{82}$ Hovell (n 1) 140.

${ }^{83}$ Hovell (n 1) 139.
} 
From this perspective she argues that the Ombudsperson is best able to respond to legitimacy gaps present in the Security Council's decision-making. ${ }^{84}$

However, the problem with marginalising domestic legal controls in favour of institutional coherence at the international level is that the smart sanctions regime suffers from not one democratic deficit, but two. The Security Council suffers from a 'double democratic deficit': ${ }^{85}$ rights and interests are neither adequately democratised on the international level, nor adequately protected by representatives in national parliaments. The consequences of this dual deficit is that Ombudsperson regime remains isolated from democratic accountability, rendering primary reliance upon it as a control mechanism inappropriate.

The disagreement between Hovell and this author regarding the priority which should be accorded to judicial review is in part driven by a difference in disciplinary perspective. The different horizons visible from the shorelines of international law and domestic public law shed very different lights on the relative utility of law and politics to protect individual rights. This difference can be summarised as follows: Hovell's vindication of the Ombudsperson and the public interest model aims to guarantee a coherent as opposed to fractured institutional response because should have a centralised means of redress in the Office of the Ombudsperson. She rightly argues that the alternative would see them at the mercy of the regime of state public law in which they reside or find themselves. ${ }^{86}$ By contrast, where legal controls are marginalised, the domestic public lawyer will look for mechanisms of democratic or political accountability to redress the balance. The balance between law and politics in the protection of both fundamental rights and state interests (however it is weighted) is part of the DNA of the discipline. Hovell's goal is the creation of procedures that are pluralist and public interest oriented, but where democratic and political means of redress are weak or insufficiently legitimate, the impulse towards judicial review becomes stronger.

The UNSC differs vastly from a domestic executive accountable to a representative legislature. Diplomats - unelected agents of national governments - are accurately described as an 'unaccountable elite'. ${ }^{87}$ Unlike the Westminster Parliament, and other legislative assemblies, the public are excluded from some meetings of the UN Security Council, and specifically, the 1267 Sanctions Committee meets in closed session. This is ostensibly to guard against the disclosure of secret intelligence. ${ }^{88}$ This compounds the need for courts to control abuse of power in the absence of input from elected representatives. This is so because terrorist suspects are a politically marginalised minority in both international and domestic discourse. Therefore, the problem common to both the international and domestic sphere is the lack of robust contestation of decisions which impinge upon minority rights. Despite the UK's parliamentary Joint Committee on Human Rights increasing political representation for 'unpopular minorities' and marginalised groups ${ }^{89}$ (such as terrorist suspects) debate on the renewal of UK terrorism legislation has been characterised as 'almost formulaic' in character. ${ }^{90}$

\footnotetext{
${ }^{84}$ Hovell (n 1) 143.

${ }^{85}$ Ian Johnstone, 'Legislation and Adjudication in the UN Security Council: Bringing Down the Deliberative Deficit’ (2008) 102 AJIL 275.

${ }^{86}$ Hovell (n 1) 118-199.

${ }^{87}$ Carne Ross, Independent Diplomat: Dispatches from an Unaccountable Elite (Hurst \& Co 2007).

${ }^{88}$ UNSCR 1735 (2006) [5]; Committee Guidelines in the amended Version of 9/12/2008, 6(a), (c).

${ }^{89}$ Paul Yowell, 'The Impact of the Joint Committee on Human Rights on Legislative Deliberation' in Murray Hunt, Hayley J Hooper and Paul Yowell (eds), Parliaments and Human Rights: Redressing the Democratic Deficit (Hart 2015) 141.

90 John Ip, ‘Sunset Clauses and Counterterrorism Legislation’ [2013] PL 74, 90.
} 
The national implementation of anti-terrorism measures remains very much about designating individuals as the 'enemy' as opposed to a 'friend', to adopt Schmitt's rubric. ${ }^{91}$ We cannot reduce the vindication of the models of procedural fairness to an either/or dichotomy in terms of law and politics. The presence of the double-democratic deficit demands the fullest utilisation of both.

The dearth of procedure for imposing sanctions further compounds the need for suspects to challenge sanctions through legal proceedings. The 1267 Committee operates under the 'no objections procedure' and requires decisions to be unanimous. ${ }^{92}$ The 'no objections procedure' requires that the Chairperson circulates the proposed decision to all members of the Committee, who may lodge any objections within ten days. But the timeframe can be as little as two working days in an emergency. Moreover, statements of the cases circulated can vary considerably in length and detail: 'the average statement...runs to about a page and a half. [At] the other extreme, one statement of case requesting the listing of seventy-four individuals included a single paragraph of justification'. ${ }^{93}$ Smart sanctions decisions usually proceed at the initiative of one state. The effect of confidentiality is that the 'capacity of members of the Committee to make an informed decision on whether to agree to a listing depends significantly on their access to intelligence information, either through their own services or their relationship with the designating state. ${ }^{94}$ Hovell acknowledges that those on the 1267 list have less chance of being delisted than detainees do of being released from Guantanamo bay. ${ }^{95}$

The 'no objections procedure' can be contrasted with procedures for imposing sanctions within British government departments which have improved due to the soft power influence of the (then) Independent Reviewer for Terrorism Legislation. ${ }^{96}$ On comparing the assetfreezing regimes with other similar sanctions regimes (such as control orders), Anderson was struck by the lack of contestation of proposals at meetings. This was remedied by drawing inspiration from parallel regimes which used procedures allowing 'assumptions to be tested by “devil's advocate" type questions, regarding for example whether the objective of an executive order might not be achieved by other means.' 97 The lack of similar procedural requirements in the 1267 Committee is particularly concerning given the dominance of the 'Five Eyes Community' which is an informal professional community consisting of the intelligence services of the UK, US, Canadian, Australian, and New Zealand governments. ${ }^{98}$

This 'double democratic deficit' is also exacerbated by the lack of transparency in the Ombudsperson's reporting process, and by its lack of connection with a representative democratic institution, which Ombudspersons usually have. For example, the United Kingdom Parliamentary generally has unrestricted access to documents, and conducts inquisitorial proceedings, as opposed to adversarial adjudication. In return for access to information its procedures are confidential, and reports issued do not contain detailed references to specific

\footnotetext{
${ }^{91}$ Carl Schmitt, The Concept of the Political (George Schwab tr, University of Chicago Press 2007) 26.

92 United Nations Security Council 1267 Committee, 'Guidelines of the Committee for the Conduct of its Work' (23 December 2016) para. 4(k)

<https://www.un.org/sc/suborg/sites/www.un.org.sc.suborg/files/guidelines_of_the_committee_for_the_conduct _of_its_work.pdf $>$.

${ }^{93}$ Chesterman (n 56) 1115.

94 ibid.

${ }^{95}$ Hovell (n 1) 20.

${ }^{96}$ David Anderson QC, 'First Report on the Operation of the Terrorist Asset-Freezing, etc. Act 2010' (The Stationary Office 2011) [6.7].

97 ibid.

${ }^{98}$ Chesterman (n 56) 1071.
} 
persons or instances. ${ }^{99}$ It is also accountable to elected Members of Parliament, which goes some way to curing the lack of transparency in its reporting process. The 1267 Ombudsperson follows a similar format to the Parliamentary Ombudsman, insofar as proceedings are private and that reports specific to individual cases are entirely confidential. The English Administrative Court acknowledged that 'the Ombudsperson is of high repute and impartial. It is clear that her reports have in some instances led to people being de-listed. However, it remains the case that the ultimate decision rests with the Sanctions Committee and no part of the Ombudsperson's report is published even in redacted form. ${ }^{100}$

Aside from its obvious lack of democratic credentials (which Hovell acknowledges) robust deliberation is not a feature of Security Council decision-making. The process to approve UNSCR 1373 in the wake of 9/11 took a mere five minutes. ${ }^{101}$ The driving force behind the lack of debate is twofold. Diplomacy is a closed, self-referential world. ${ }^{102}$ Diplomats and representatives of the intelligence community are not politically accountable: unlike parliamentarians, they cannot be removed by the exercise of constituent power. Secondly, it is notoriously difficult to inject security discourse with minority viewpoints: the 'friend' or 'enemy' distinction at the core of Schmitt's work continues to dominate discourse on antiterrorism policy. ${ }^{103}$ According to an experienced former British diplomat '[i]n order for diplomacy to function as a discourse...the sides involved are required to delineate themselves into discrete sets: Us and Them'. ${ }^{104}$ Schmitt's friend/enemy distinction still characterises political rhetoric towards suspected minority groups post-9/11.

Recourse to binding rulings from domestic courts must help counter-balance the double democratic deficit. Once an individual is identified as a member of the UNSC 1267 list, he or she is likely to be politically marginalised. When we consider the litigant in a national constitutional order, we see an individual without political power, reliant upon the legal system. An individual right of petition, in the presence of independent adjudicators, leading to a final and coercive remedy ${ }^{105}$ are all features which the Office of the Ombudsperson lacks. Administrative procedures of a Kafkaesque nature (such at the 1267 regime) are those which 'take away the participants' ability to engage in rational planning about their situation. [The] participant begins to see himself as an object, susceptible to infinite manipulation by "the system". ${ }^{106}$ In this regard, recourse to the legal process to redress the balance between the individual and executive power is essential. The legal process, at the national level, becomes the only viable option. This has been true of Libyan citizens resident in the United Kingdom who were subjected to the 1267 regime on the recommendation of the UK Foreign and Commonwealth Office (FCO). In an action for alleged illegality against the FCO, the Administrative Court took the view that the Security Council may be more likely to remove a suspect from the Consolidated List if 'a British court has ruled that the FCO acted unlawfully

\footnotetext{
${ }^{99}$ Carol Harlow and Richard Rawlings, Law and Administration (3rd edn CUP, 2009), Ch 12.

${ }^{100}$ R (On the Application of Hany Youssef) v Foreign Secretary [2013] 1 QB 906; [2012] EWHC 2091 (Admin) [50], emphasis added.

${ }^{101}$ United Nations Security Council, 4385 ${ }^{\text {th }}$ Meeting 28 September 2001, 9.55pm-10.00pm EST (S/PV.4385) (New York, USA).

${ }^{102}$ Carne Ross, Independent Diplomat: Dispatches from an Unaccountable Elite (Hurst \& Co, 2007) 7

${ }^{103}$ Carl Schmitt \& George Schwab (trs), The Concept of the Political (University of Chicago Press 2007$) 26$.

104 Ross (n 87) 83.

105 Jeff A King, 'The Instrumental Value of Legal Accountability’ in Nicholas Bamforth and Peter Leyland (eds), Accountability in the Contemporary Constitution (OUP 2013) 127.

106 Jerry L Mashaw, Bureaucratic Justice: Managing Social Security Disability Claims (Yale University Press 1983) 91.
} 
in requesting his name to be included on the Consolidated List in the first place'. ${ }^{107}$ For the politically marginalised, the availability of binding legal procedural guarantees is essential. The value of such legal accountability stems from the fact that it is above all 'unambiguous'. ${ }^{108}$

\section{The role of courts in promoting due process}

Hovell argues that domestic and supra-national courts should recognise that their role is a 'qualified one,' insofar as they should understand that they are persuasive as opposed to determinative authorities on the legal position of the sanctions regime. ${ }^{109}$ This is because courts invalidating regulations implementing smart sanctions risk setting 'informal precedents' and 'opening up dangerous holes in the sanctions net. ${ }^{110}$ Hovell argues that courts should instead occupy a 'fertile middle ground' between the extremes of 'law creation and law enforcement, binding and non-binding law, judicial and political supremacy, and international and domestic legal orders.' 111 By contrast this author believes that binding domestic decisions should serve as demarcations of the outer limits of the space in which Hovell's pluralistic debate on the nature of fairness can take place, and of catalysing action on the international plane.

There is no doubt that Hovell is correct in stating that the role of courts vis-à-vis the Security Council is qualified. This is an important and accurate insight. In order to bring the force of that insight home, Hovell problematizes the rulings in Kadi ${ }^{112}$ and Ahmed ${ }^{113}$ to explain that they create an unsatisfactory deadlock between the competing imperatives of due process and security. ${ }^{114}$ However, public lawyers striving for a constitutional - as opposed to institutionally coherent - vision of procedural protection, will read the impact of the rulings in these cases differently. This is by no means fatal to Hovell's project of promoting a 'normatively rich' vision of fairness. ${ }^{115}$ Instead, it is merely argued that we should see such binding rulings as a complement to the Ombudsperson procedure.

The Kadi (No. 2) decision exemplifies the need for a control model of administrative law (setting the outer limits of acceptable conduct) to complement the procedural innovation of the Ombudsperson. Kadi was removed from the UN Sanctions Committee List (the 1267 Consolidated List) on 5 October 2012 after consideration by that Committee of both Mr Kadi's request and the report of the UNSC Ombudsman. Nonetheless, Kadi's case was heard by the European Court of Justice because it raised important issues of principle in European Union law. ${ }^{116}$ The European Court of Justice invalidated the EU Regulations ${ }^{117}$ on which Kadi's

\footnotetext{
${ }^{107} R$ (Maftah and Khaled) v Foreign Secretary [2010] EWHC 1868 (Admin) [15].

${ }^{108}$ Michael Bovens, 'Analysing and Assessing Accountability: A Conceptual Framework' (2007) 13(4) ELJ 447, 456.

109 Hovell (n 1) 122.

110 Hovell (n 1) 119.

${ }^{111}$ Hovell (n 1) 122.

112 Kadi and Al Barakaat International Foundation v Council and Commission (Kadi No. 1) [2008] ECR I-

6351; Yassin Abdullah Kadi v. Commission (No. 2) [2010] ECR 00000 (30 September 2010)

${ }^{113}$ Mohammed Jabar Ahmed v HM Treasury (Ahmed No. 1) [2010] UKSC 2; [2010] 2 WLR 378.

${ }^{114}$ Hovell (n 1) 153.

115 Hovell (n 1) 4.

${ }^{116}$ Commission v Kadi (Kadi No. 2) [2013] ECR 00000 (Grand Chamber).

117 Council Common Position (EC) 2001/931/CFSP of Dec. 27, 2001 on the application of specific measures to combat terrorism [2001] OJ L 344/93 implementing UNSCR 1373 and Council Regulation (EC) No. 2580/2001 of Dec. 27, 2001 on specific restrictive measures directed against certain persons and entities with a view to combating terrorism [2001] OJ L 344/70.
} 
listing was based because they constituted a violation of the right to 'effective judicial protection'. ${ }^{118}$

Kadi's quest to secure adequate reasons for his listing continued. The Grand Chamber reemphasised the ruling in Kadi (No. 2) and clarified that judicial review 'cannot be restricted to an assessment of the abstract cogency in the abstract of the reasons relied on' ${ }^{119}$ Regarding the standard of disclosure required in review proceedings, the Court took the view 'that the information or evidence produced should support the reasons relied on against the person concerned. ${ }^{\text {'120 }}$ The European Court of Human Rights opted for a similar standard of disclosure to make judicial review sanctions imposed on the basis of 'closed' or 'secret' evidence compatible with the right to a fair trial enshrined in Article 6 ECHR. Review proceedings required that: '[The] detainee was provided with sufficient information about the allegations against him to enable him to give effective instructions' to legal counsel acting on his behalf. ${ }^{121}$ In the Ahmed (No. 1) ruling, the UK Supreme Court held that legislation permitting UN sanctions to be lawfully imposed required Parliament to 'squarely confront the political cost' of interference with fundamental rights, and to do so expressly in primary legislation. ${ }^{122}$

The strongly articulated principles of the protection of procedural fairness and fundamental rights articulated in Kadi (No. 2) ${ }^{123}$, Ahmed (No. 1) ${ }^{124}$, and Home Secretary $v$ AF (No. 3) ${ }^{125}$ should not be marginalised to a 'fertile middle ground'. ${ }^{126}$ Instead, a better conception of the work these disparate rulings are doing is that they set the outer limits of a dialogue between governments, intelligence agencies, and the courts as to how process values facilitate the vindication of substantive fairness. This is particularly important in view of the impact of smart sanctions, appropriately described as 'draconian measures, unlimited as to time and quantum...the consequences of which may be devastating' ${ }^{127}$ So long as such power is exercised beyond the reach of the protections of criminal procedure or the democratic process it remains important for any discourse to be ring-fenced by an outer limit of legal principle.

Hovell expresses concern that courts seized of review would be faced with 'difficult and largely unguided substantive choices among competing values, and indeed among inevitably controverted political, social, and moral conceptions of appropriate responses to threats to international peace and security. ${ }^{128}$ However, judges are seized of national security review tend to be sensitive to the subject matter at hand, and avoid making unguided substantive choices among competing imperatives. To this end, the interaction between procedural fairness and substantive review is also symbiotic. The substantive standard of review has also long been considered to 'be "a sliding scale of review"...the degree of intensity of judicial scrutiny depends on the context of the issues before the court'. ${ }^{129}$ In respect of the aspect of the security state under review, the courts have emphasised that the principle of

\footnotetext{
${ }^{118}$ Kadi (No. 2) (n 41) [119].

119 ibid.

${ }^{120}$ Kadi (No. 2) (n 41) [122], emphasis added.

${ }^{121} A$ and Others $v$ United Kingdom [2009] ECHR 301 [220].

${ }^{122} R v$ Home Secretary, ex parte Simms [2000] 2 AC 115; [1999] UKHL 33, per Lord Hoffmann.

${ }^{123}$ Kadi (No. 1) (n 112).

${ }^{124}$ Ahmed (n 114).

${ }^{125}$ AF (No. 3) (n 29).

126 Hovell (n 1) 122.

${ }^{127}$ Case T-85/09 Yassin Abdullah Kadi v Commission (No. 2) [2010] ECR 00000 [83].

128 Hovell (n 1) 106.

${ }^{129}$ Arthurs, Re Judicial Review [2010] NIQB 75 [26].
} 
legality - whilst ordinarily guaranteeing the protection of fundamental rights from implied legislative intrusion - can be used to ration access to judicial review where the context requires. ${ }^{130}$ The Strasbourg jurisprudence also tailors the intensity of procedural protection according to the importance of the human rights being 'traded off' against a national security interest. ${ }^{131}$ Litigation on asset-freezing and other parallel security powers has also led certain first instance judges to develop a growing body of expertise in the field of national security. This has, in turn, been recognised by the appellate courts that they 'are also much better placed to develop consistent practice for dealing with orders of this kind, and to provide continuing supervision of their making, variation, and implementation.' ${ }^{\text {132 }}$

Moreover, legally demarcating a baseline of procedural fairness does not necessarily unduly burden the Security Council or the sanctions regime. The disclosure thresholds required to guarantee fairness are also necessarily vague. ${ }^{133}$ This is because the imposition of categorical standards in this area (i.e. standards that mirror speed limits, or acceptable blood-alcohol ratios) run the risk of fettering legitimate discretion as to what should be disclosed or who should be designated a suspect. ${ }^{134}$ A categorical standard would potentially endanger national security by mandating too broad a standard of disclosure, or alternatively, by mandating too narrow a standard it would risk circumscribing procedural fairness. In this regard, Hovell is right to dismiss the instrumentalist model as irrelevant to the discussion.

Neither are judicial decisions of this nature taken in a vacuum. In this regard Hovell perhaps overstates the risk that binding legal rulings will fracture the operation of the sanctions regime. ${ }^{135}$ Courts and legislative institutions remain sensitive to the administrative consequences of individual rulings with knock on consequences for legal validity of administrative regimes. In Kadi (No. 1) the EU's highest court stayed the effect of the annulment the EU Regulations to maintain Kadi's listing and to allow coordination on the diplomatic level (between the Sanctions Committee and relevant EU officials) to facilitate a disclosure of the 'narrative summary of reasons for listing'. Similarly, in Ahmed (No. 1) when Orders in Council implementing Resolution 1267 were struck down by the UK Supreme Court, Parliament enacted 'fast-track' primary legislation to imbue the national implementation measures with the necessary constitutional authority. The Terrorist Asset-freezing (Temporary Provisions) Act 2010 was rushed through Parliament over two days in February. In respect of the UNSCR 1267 regime new regulations were enacted during the same period ${ }^{136}$ allowing individuals to apply to Administrative Court for judicial review of any decision of the British government to list individuals.

Hovell's model clearly supports a dialectical partnership between courts and the Security Council. ${ }^{137}$ However, judicial review is neither a threat to this dialogue, nor a threat to the effectiveness of the sanctions regime. Therefore, it is more appropriate to view the finality of legal accountability, and the crystallisation of national constitutional standards as part of a dialogue, as opposed to a part of a middle ground, or as a potential threat to the hierarchy of international norms. The power imbalance between the Security Council and

\footnotetext{
${ }^{130} R$ (Privacy International) v Investigatory Powers Tribunal [2017] WLR(D) 775; [2017] EWCA Civ 1868 [25].

${ }^{131}$ Compare Al-Nashif v Bulgaria (Art 8 ECHR) [2002] ECHR 502 with A and Others v United Kingdom [2009] ECHR 301 (Art 5 ECHR).

${ }^{132}$ Home Secretary v AP [2011] 2 AC 1l; [2010] UKSC 24, Lord Brown [19].

133 Timothy Endicott, 'Law is Necessarily Vague’ (2001) 7(4) Legal Theory 379.

${ }^{134}$ Endicott (n 133) 380.

135 Hovell (n 1) 119.

136 The Al-Qaida and Taliban (Asset-Freezing) Regulations 2010, SI 2010/1197.

${ }^{137}$ Hovell (n 1) 126.
} 
municipal courts (and even the European Union judicature) effectively means that no single jurisdiction can destabilise the hierarchy of norms. They are, as Hovell correctly states, 'informal precedents'. ${ }^{138}$ Their value as categorical claims about the requirements of due process serves the ongoing dialogue about due process Hovell desires in three ways: first, the ability of legal rulings to bind national executives sends a strong signal as to the nature of procedural reform required to legitimise international security initiatives. Secondly, the publication of reasoned judgements allows the general public to see that national security bureaucracies are subject to the rule of law. Thirdly, the vindication of legal process definitively reasserts the 'public' values in a legal order against the worst excesses propagated in the name of (inter)national security. ${ }^{139}$ In this regard, a public lawyer's support for judicial review of this nature can be seen as serving Hovell's model, as opposed to undermining it.

\section{An alternative conception of judicial review of security powers}

Hovell puts forward three main objections to judicially enforced human rights law as a vehicle for due process standards. First, she argues that judicial review is 'frozen in time' ${ }^{140}$ and therefor unresponsive to shifting security imperatives. Secondly, she argues that the division between civil and criminal proceedings in most jurisdictions is unhelpful because it is not a feature of Security Council decisions. ${ }^{141}$ Secondly, human rights law also potentially paves the way for sanctions being classified as 'civil' in nature, and thus attracting lower standards of procedural protection. ${ }^{142}$ Finally, she argues that courts are unsuitable for balancing the competing imperatives of ensuring procedural fairness and protecting classified. To this end, she expresses the concern that courts seized of judicial review would be 'to make difficult and largely unguided substantive choices among competing values' ${ }^{143}$

Judicial review of (inter)national security powers in the English legal system has come far since its nadir at the turn of the twentieth century, when it was 'at worst dismal, at best ambiguous.' ${ }^{144}$ The definition of national security adopted by the English courts now recognises the challenge inherent in legally controlling an increasingly broad concept. The 2015 National Security Risk Assessment included cyber-attacks, an international military crisis, international terrorism, and environmental disasters as the foremost threats to national security. ${ }^{145}$ The law recognises the need for flexibility. In Rehman, the leading English authority on the legal definition of (inter)national security, the House of Lords recognised that against a foreign state may be capable of indirectly affecting the national security interest and so afforded the executive latitude to combat such action. ${ }^{146}$ In respect of the temporal dimension Lord Slynn took the view that 'there must be a real possibility of an adverse effect on the United Kingdom but I do not accept that it has to be direct or immediate' ${ }^{147}$ Both the

\footnotetext{
138 Hovell (n 1)118-119.

139 A v Home Secretary (No.1) (Belmarsh) [2004] UKHL 56; [2005] 2 AC 68.

${ }^{140}$ Hovell (n 1) 149.

${ }^{141}$ Hovell (n 1) 43.

142 Hovell (n 1) 44.

143 Hovell (n 1) 106.

144 David Dyzenhaus, The Constitution of Law: Legality a Time of Emergency (CUP 2006) 17.

${ }^{145}$ HM Government, National Security Strategy and Strategic Defence and Security Review 2015 (Cm 9161).

${ }^{146}$ Home Secretary v Rehman [2001] UKHL 47; [2003] 1 AC 153.

${ }^{147}$ Rehman (n 146) Lord Slynn.
} 
English common law and the ECHR reflect a 'spectrum' of different levels of procedural protection, rather than a single conception underpinned by a single normative justification. ${ }^{148}$ Review for procedural fairness is never done with a view to an instrumental search for 'correctness' which Hovell correctly points out as having the potential to lead to arbitrary results. ${ }^{149}$

In respect of the need to safeguard secret intelligence, the English courts have also vindicated the principle of 'originator control'. ${ }^{150}$ The essence of the control principle is that 'confidentiality is vested in the country of the services which provides the information: it never vests in the country [or organisation] which receives the information.' ${ }^{151}$ This principle takes centre-stage in the publicly disclosed agreements between the Ombudsperson governing access to classified intelligence agreements held by member states. ${ }^{152}$ It has been described as: 'the most jealously protected national security privilege of all'. ${ }^{153}$

Neither should the dichotomy between civil and criminal procedure necessarily be seen as a reason to avoid binding legal standards of procedural fairness. The civil/criminal divide is necessarily present in this context because the 1267 regime forms part of a system of 'preventive justice', discussed above. ${ }^{154}$ The rationale for such preventative measures is that conventional criminal justice occurs after the fact, i.e. it punishes wrongs after the damage has been done. In other words, criminal justice can neither assess the risk of serious harm from terrorism, nor do anything to prevent its occurrence. Secondly, the criminal justice model is a 'victim of its own success' because its 'structures and principles... are so rigorous as to lead authorities to pursue proceedings elsewhere in less procedurally rigorous environments. ${ }^{\text {'155 }}$ Judicial review of security powers has come far, given that the 1267 regime, and other parallel regimes designed to facilitate pre-emptive security powers, were initially designed to be effectively 'court proof'.

Lord Lloyd's seminal 1996 report Inquiry into Legislation Against Terrorism cautioned that: 'It is a dangerous illusion to believe that one can "protect" liberal democracy by suspending liberal rights and forms of government." 156 The classification of smart sanctions as 'infringing upon civil rights' ${ }^{157}$ is a necessary tool to allow courts to subject them to legal standards of fairness. Although human rights based judicial review has arguably been characterised by its 'deep ambivalence' to power ${ }^{158}$, it remains a more necessary component of the picture than Hovell suggests.

\footnotetext{
${ }^{148}$ Eva Nanopoulos, 'European Human Rights Law and the Normalisation of the 'Closed Material Procedure': Limit or Source?’ (2015) 78(6) MLR 913, 922.

149 Hovell (n 1) 85-87.

${ }^{150}$ Binyam Mohamed v Foreign Secretary [2010] EWCA Civ 65; [2011] QB 218.

${ }^{151}$ Binyam Mohamed (n 150) [5].

152 The agreements between the Ombudsperson and Austria and Romania are accessible. A list of other countries with agreements can also be viewed at: https://www.un.org/sc/suborg/en/ombudsperson/classified_information

${ }^{153}$ Hans Born and Ian Leigh, International Intelligence Cooperation and Accountability (Studies in Intelligence) (Routledge 2012) 5.

154 Zedner, 'Preventive Justice or Pre-Punishment' (n 75) 174.

155 Zedner, 'Preventive Justice or Pre-Punishment’ (n 75) 201.

${ }^{156}$ Rt. Hon. Lord Lloyd of Berwick, 'Inquiry into Legislation against Terrorism' (Cm 3420, 1996) 58.

${ }^{157}$ Art 6(1) ECHR.

158 Nanopoulos (n 148) 931.
} 


\section{Conclusion}

The differences between this essay's perspective and Hovell's approach can effectively be reconciled as a difference in disciplinary perspective. Public international law understandably focuses upon the source of the smart sanctions power and the need to find a vision of fairness which squares with the accepted hierarchy of norms. This makes privileging political accountability mechanism and soft-power influence an instinctive solution. However, if we reimagine the smart sanctions regime from the perspective of the targeted individual, as the thought experiment in the introduction does, then the argument in favour of binding legal measures becomes compelling. This perspective is the natural preserve of the domestic public lawyer, who tends to see control of power as an interrelationship between law and representative politics. As this is sorely lacking at both the international level and in domestic constitutions, judicial review becomes the most attractive remedy.

Hovell's rigorous work should be engaged with by domestic public lawyers and international lawyers alike. It presents a thought provoking set of solutions to the challenge of holding the global security apparatus to account. The argument that due process should strive to legitimize the exercise of substantive power is correct in aspirational terms. Moreover, despite the ability of courts to create binding norms of procedural justice and control the most irrational excesses security powers ${ }^{159}$, Hovell brings the fact that legal process alone is an insufficient counterweight to security powers into sharp focus. This inability of legality alone to control the executive in the (inter)national security context is undoubtedly influenced by the relatively modest purpose of administrative law, which is 'to keep officials from straying beyond some large and loose requirements of clear statutory language'. ${ }^{160}$ Administrative law does this by employing equally loose concepts of control such as 'legality', 'rationality', 'proportionality', and 'fairness', and 'minimum thresholds' of disclosure. Within those loosely-defined boundaries 'there lies a gigantic policy space, invisible to the legal order.' ${ }^{\text {, }}$ It is here that Hovell's astute analysis - combined with binding legal standards - can make inroads into this vacuum.

Hovell's analysis makes a strong contribution by demonstrating the importance of noncurial norms of procedural justice. All too often lawyers run the risk of venerating the legal process, oblivious to the context it seeks to regulate. In The Power of Process the reader is squarely confronted with the difficulties the international context presents. Hovell's major contribution is to highlight how the Ombudsperson structure can function in this context, and to make clear that any attempts to force either a state-like structure or to create an international court structure to review acts of the Security Council would ultimately be redundant. Focussing on the Ombudsperson as a means to ensure that the right procedural rules are formulated for the Sanctions Committee is a worthwhile endeavour. However, this is necessary but not sufficient in and of itself. Any analysis of the smart sanctions regime must account for the perspective of the Security Council and the designated individual. Reform of the Office of the Ombudsperson is central and important, but must take place against the backdrop of binding legal norms which provide a back-stop mechanism to protect individual rights.

\footnotetext{
${ }^{159}$ Bank Mellat (No. 1) (n 46), Bank Mellat v Her Majesty’s Treasury (No. 2) [2013] UKSC 39.

${ }^{160}$ Mashaw (n 106) 9.

161 ibid.
} 